\title{
First country record of Trachycephalus mesophaeus (Hensel, 1867) (Amphibia, Anura, Hylidae) in Argentina
}

\author{
Jordi A. Garcia-Marsà1, Federico L. Agnolín¹,2, Julia S. D’Angelo \\ 1 Museo Argentino de Ciencias Naturales "Bernardino Rivadavia", Av. Ángel Gallardo 470, Buenos Aires, C.P. C1405DJR, Argentina. 2 Fundación \\ de Historia Natural "Félix de Azara", Universidad Maimónides, Hidalgo 775, Buenos Aires, C.P. C1405BDB, Argentina. \\ Corresponding author: Jordi Alexis Garcia Marsà, jagmdarwinista@gmail.com
}

\begin{abstract}
We report the first record of the Porto Alegre Golden-eyed Treefrog, Trachycephalus mesophaeus (Hensel, 1867), from Argentina based on a single specimen collected in the 1980s at Las Lomitas, province of Formosa, northeastern Argentina. This new record, within the Chacoan Biogeographical Region, is separated by more than $1300 \mathrm{~km}$ from its main range in the Atlantic Forest.
\end{abstract}

\section{Keywords}

Amazon Basin, Atlantic Forest ecoregion, Chacoan ecoregion, geographical distribution, Pleistocene.

Academic editor: Raúl Maneyro | Received 28 October 2019 | Accepted 7 January 2020 | Published 28 February 2020

Citation: Garcia-Marsà JA, Agnolín FL, D’Angelo JS (2020) First country record of Trachycephalus mesophaeus (Hensel, 1867) (Amphibia, Anura, Hylidae) in Argentina. Check List 16 (1): 219-222. https://doi.org/10.15560/16.1.219

\section{Introduction}

Trachycephalus Tschudi, 1838 is an arboreal tree frog genus composed of 17 species and distributed along the lowlands of Mexico and south in Central and South America (Frost 2019). In South America, Trachycephalus is distributed along the western slopes of the Andes in Peru and Ecuador and the eastern slopes of the Andes, south to northern Argentina and eastern Brazil (Frost 2019).

The Porto Alegre Golden-eyed Tree Frog, Trachycephalus mesophaeus (Hensel, 1867), was originally described from near the city of Porto Alegre, Rio Grande do Sul state, Brazil (Hensel 1867). The species was collected in several localities in the Atlantic Forest in the states of Rio Grande do Sul, Santa Catarina, Paraná, São Paulo, Minas Gerais, Rio de Janeiro, Espiríto Santo, Bahia, Pernambuco, Sergipe, and Alagoas (Haddad et al. 2013; Dias et al. 2014; Santana et al. 2016). Trachycephalus mesophaeus occurs in primary and secondary forests and forest edges, as well as in permanent freshwater marshes (Carvalho-e-Silva and Garcia 2004; Haddad et al. 2013; Prado et al. 2003) and highly anthropized habitats (Carvalho-e-Silva and Garcia 2004; Santana et al. 2016).

Herein, we report Trachycephalus mesophaeus from Argentina for the first time and greatly increase its geographical distribution in southern South America.

\section{Methods}

In the spring of 1986, one specimen of Trachycephalus mesophaeus from the city of Las Lomitas, Formosa Province, Argentina was collected and euthanized by anesthetic overdose ( $5 \%$ lidocaine), fixed in $10 \%$ formalin, preserved in $70 \%$ ethanol, and deposited at the Fundación de Historia Natural "Félix de Azara" (CFA), Universidad Maimonides, C.A.B.A., Argentina. The examined material was photographed with a Nikon 
D3100 digital camera. The species was identified using the descriptions by Bokermann (1966), Lema and Martins (2011), and Hensel (1867).

\section{Results}

New record (Fig 1). Argentina 1 adult specimen, CFAAn-88; Formosa Province, Patiño department, Las Lomitas; $24^{\circ} 42^{\prime} 26^{\prime \prime} \mathrm{S}, 060^{\circ} 35^{\prime} 40^{\prime \prime} \mathrm{W}$ (WGS 84); $130 \mathrm{~m}$ a.s.l.; 3 Sept. 1986; José W. Soroka and José María Gallardo leg.

In Formosa Province the Chaco biogeographical region is separated into the "Wet Chaco" region, which extends in the east from the Paraguay River to the $60^{\circ} \mathrm{W}$ meridian, and the "Dry Chaco", which extends over the western half of the biogeographical area (Di Giácomo 2005). Las Lomitas is at the $60^{\circ} 35^{\prime} 40^{\prime \prime} \mathrm{W}$ meridian, which is near to the boundary between the Wet and Dry Chaco biogeographical realms.

Identification. The specimen (Fig. 2) is identified as $T$. mesophaeus by its coloration, which is characterized by a large, uniform, dark brown dorsal fleck from between the eyes down to the anus, bordered by broad, yellowish lateral stripes, and absence of cross-bars in the limbs (Bokermann 1966; Lutz 1973; Lema and Martins 2011; Soares et al. 2012); the description by Hensel (1867) was also consulted. The coloration clearly distinguishes this species from related taxa, including the geographically close T. typhonius (Linnaeus, 1758) (Kwet and Solé 2008), which may be a species complex because of its wide distribution and different morphologies ( McDiarmid 1968; Cei 1980; Duellman 2001; Eterovick and Sazima 2004; Lavilla et al. 2010; Frost 2019). It is not impossible that the specimen CFA-An- 88 might belong to a still unknown population of the T. typhonius complex. However, because this specimen shares all morphological attributes of T. mesophaeus, we opt to consider this specimen as this species and not T. typhonius.

\section{Discussion}

There are several clues that may explain the finding of T. mesophaeus 35 years ago in an area far from this speciesmain geographical distribution and why it was not found more recently. Firstly, T. mesophaeus is difficult to find outside its breeding season. Most specimens in collections were collected during the reproductive frenzy, whereas during the non-reproductive season, the species is very secretive and difficult to find (Prado et al. 2003; Carvalho-e-Silva and Garcia 2004; Haddad et al. 2013). Secondly, the Chacoan biogeographical region is still poorly explored and vertebrates may go unnoticed for many years, such as was the case for the Chacoan Opossum, Chacodelphys formosa Shamel, 1930), which for more than 80 years was only known by a single specimen but was rediscovered in 2006, with most specimens being skulls recovered from owl pellets (Teta et al. 2006; Teta and Pardiñas 2007). Thus, it is not improbable that T. mesophaeus has healthy populations in the Chaco Area that are still unknown.

Another possibility is that T. mesophaeus was present in the Chacoan Ecoregion in the 1980s but is now extirpated there. Local extirpations of anurans are not uncommon, especially in areas strongly modified by agricultural activities (Agnolín and Guerrero 2017). Because the Chacoan Ecoregion is undergoing strong degradation (Periago et al. 2015), the extirpation of $T$. mesophaeus there is a possibility. In this regard, despite that this species shows some tolerance to modified habitats (Santana et al. 2016), recent studies have shown that it appears to be severely negatively affected to strong environmental degradation (Prado et al. 2003; Carvalhoe-Silva and Garcia 2004; Haddad et al. 2013).

On the other hand, the finding of a typically Atlantic Forest species in the Chacoan region is not uncommon, even though, in the case of T. mesophaeus, the occurrence in the Chacoan region is more than $1300 \mathrm{~km}$ from the species' main geographic range in the Atlantic Forest. It is well known that many species are disjointly distributed in the Atlantic Forest and the Amazon Basin, with these biomes separated from one another by the broad diagonal of xeric habitats comprising the Chaco (Ab'Saber 1977). There is evidence supporting a past connection of the Atlantic Forest with the Amazon Basin through this dry vegetation diagonal during the latest
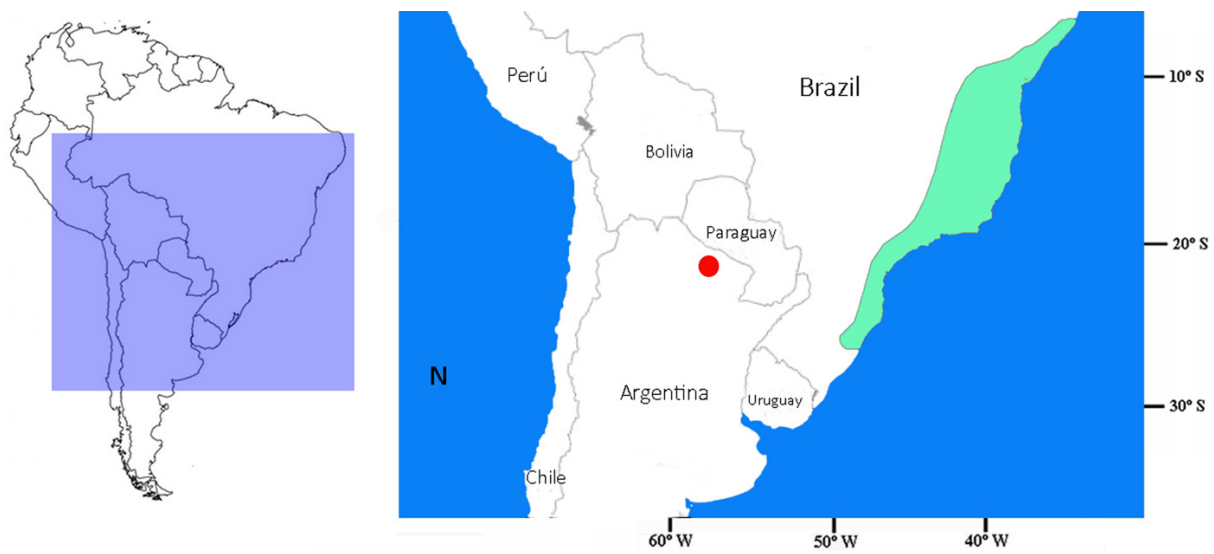

Figure 1. Geographic distribution of Trachycephalus mesophaeus, showing the new record in Las Lomitas (Formosa Province; red circle) and previous records (in green). 

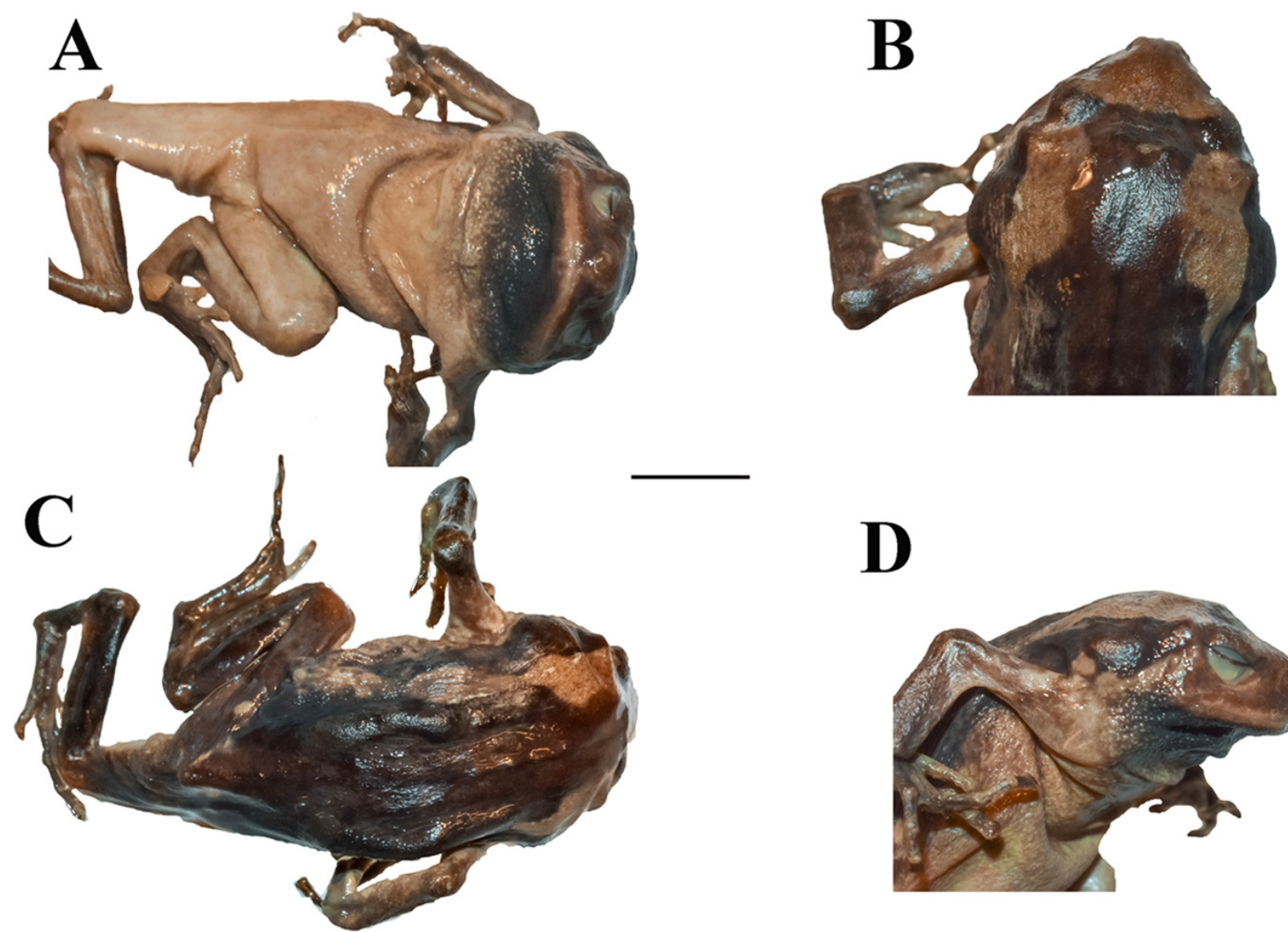

Figure 2. Trachycephalus mesophaeus. A. Ventral view. B. Dorsal view of the head. C. Dorsal view. D. Lateral view. Scale bar $=1 \mathrm{~cm}$.

Pleistocene when wetter periods allowed the expansion of gallery forests (Costa 2003; Auler et al. 2004; Wang et al. 2004). Several vertebrate species show a distribution that reflects such an ancient connection (Batalha-Filho et al. 2013; Cabanne et al. 2019), and the presence of a relictual population of T. mesophaeus in the Chacoan Ecoregion may reflect the once more widespread distribution of gallery forests and associated fauna.

\section{Acknowledgements}

We thank S. Bogan (Fundación de Historia Natural "Félix de Azara") for allowing the revision of collections under his care. We also thank Adrián Giacchino for his support. We thank the reviewers for their helpful corrections and advice. We give special thanks to J. Soroka, who provided valuable information about the specimen here reported.

\section{Authors' Contributions}

All authors collected the data, made identifications, wrote the manuscript, and prepared the figures.

\section{References}

Ab’Sáber AN (1977) Os domínios morfoclimáticos na América do Sul. Primeira aproximaçao. Geomorfología 52: 1-21.

Agnolín F, Guerrero EL (2007) Local extinction of Melanophryniscus montevidensis (Anura: Bufonidae) in the Argentine pampas.
Check List 13 (4): 11-15. https://doi.org/ 10.15560/13.4.11

Auler AS, Wang X, Edwards RL, Cheng H, Cristalli PS, Smart PL, Richards DA (2004) Quaternary ecological and geomorphicchanges associated with rainfall events in presently semi-arid north-eastern Brazil. Journal of Quaternary Science 19: 693-701. https://doi.org/10.1002/jqs.876

Batalha-Filho H, Fjeldså, J, Fabre, PH, Miyaki, CY (2013) Connections between the Atlantic and the Amazonian forest avifaunas represent distinct historical events. Journal of Ornithology 154 (1): 41-50. https://doi.org/10.1007/s10336-012-0866-7

Bokermann WCA (1966) Lista anotada das localidades tipo de anfibios brasileiros. São Paulo, Serviço de Documentação, Reitoria da Universidade de São Paulo, 183p.

Cabanne GS, Campagna L, Trujillo-Arias N, Naoki K, Gómez I, Miyaki CY, Santos FR, Dantas GP, Aleixo A, Claramunt S, Rocha A (2019) Phylogeographic variation within the Buff-browed Foliage-gleaner (Aves: Furnariidae: Syndactyla rufosuperciliata) supports an Andean-Atlantic forests connection via the Cerrado. Molecular Phylogenetics and Evolution 133: 198-213. https://doi. org/10.1016/j.ympev.2019.01.011

Carvalho-e-Silva SP, Garcia P (2004) Trachycephalus mesophaeus. The IUCN Red List of threatened species. Version 2014.3. http:// www.iucnredlist.org. Accessed on: 2019-02-19.

Cei JM (1980) Amphibians of Argentina. Monitore Zoologico Italiano 2, Nuova Serie. Universita degli studi di Firenze, Firenze, $\mathrm{xii}+609 \mathrm{pp}$.

Costa MH, Botta A, Cardille J (2003) Effects of large-scale change in land cover on the discharge of the Tocantins River Amazonia. Journal of Hydrology 283: 206-217. https://doi.org/10.1016/ S0022-1694(03)00267-1

Di Giácomo AS (2005) Áreas importantes para la conservación de las aves en la Argentina. Sitios prioritarios para la conservación de la biodiversidad. Aves Argentinas/Asociación Ornitológica del Plata, Buenos Aires, 514 pp.

Dias IR, Medeiros TT, Vila Nova MF, Solé M (2014) Amphibians 
of Serra Bonita, southern Bahia: a new hotpoint within Brazil's Atlantic Forest hotspot. ZooKeys 449: 105-130. https://doi.org/ 10.3897/zookeys.449.7494

Duellman WE (2001) Hylid frogs of Middle America, expanded edition. Society for the Study of Amphibians and Reptiles, Ithaca, $1250 \mathrm{pp}$

Eterovick PC, Sazima I (2004) Anfibios da Serra do Cipó/Amphibians from the Serra do Cipó Minas Gerais - Brasil. PUC Minas, Belo Horizonte, $150 \mathrm{pp}$.

Frost DR (2019) Amphibian species of the world: an online reference. Version 6.0. http://research.amnh.org/herpetology/amphibia/index.html. American Museum of Natural History, New York, USA. Accessed on: 2019-09-16.

Haddad CFB, Toledo LF, Prado CPA, Loebmann D, Gasparini JL, Sazima I (2013) Guia dos anfíbios da Mata Atlântica: diversidade e biologia. Anolis Books, São Paulo, 544 pp.

Hensel R (1867) Beiträge zur Kenntnis der Wirbelthiere Südbrasilens Archiv für Naturgeschichte 33: 120-162.

Kwet A, Solé M (2008) A new species of Trachycephalus (Anura: Hylidae) from the Atlantic Rain Forest in southern Brazil. Zootaxa 1947: 53-67. https://doi.org/10.11646/zootaxa.1947.1.3

Lavilla EO, Langone JA, Padial JM, Rafael O (2010) The identity of the crackling, luminescent frog of Suriname (Rana typhonia Linnaeus, 1758) (Amphibia, Anura). Zootaxa 2671: 17-30.

Lema T, Martins LA (2011) Anfíbios do Rio Grande do Sul. Catálogo, diagnose, distribuição e iconografia. ediPUCRGS, Porto Alegre, 196 pp.

Lutz B (1973) Brazilian species of Hyla. University of Texas Press, Austin, 265 pp.

McDiarmid RW (1968) Populational variation in the frog genus Phry- nohyas Fitzinger in Middle America. Contributions in Science, Los Angeles County Museum 134: 1-25.

Periago ME, Chillo V, Ojeda RA (2015) Loss of mammalian species from the South American Gran Chaco: empty savanna syndrome? Mammal Review 45 (1): 41-53. https://doi.org/10.1111/mam.12031

Prado G, Borgo JH, Abrunhosa PA, Wogel H (2003) Comportamento reprodutivo, vocalização e redescrição do girino de Phrynohyas mesophaea (Hensel, 1867) do sudeste do Brasil (Amphibia, Anura, Hylidae). Boletim do Museu Nacional, Nova Série, Zoologia 510: 1-11.

Santana DO, Santos Almeida RP, Caldas FLS, dos Reis Dias, EJ and Gomes Faria R (2016) New records of Trachycephalus mesophaeus (Hensel, 1867) (Anura: Hylidae) from Atlantic Forest in Sergipe state, Brazil. Herpetology Notes 9: 255-260.

Soares ML, Iop S, Santos TG (2012) Expansion of the geographical distribution of Trachycephalus typhonius (Linnaeus, 1758) (Anura: Hylidae): first record for the state of Rio Grande do Sul, Brazil. Check List 8: 817-818. https://doi.org/10.15560/8.4.817

Teta P, Pardiñas UFJ (2007) Mammalia, Didelphimorphia, Didelphidae, Chacodelphys formosa (Shamel, 1930): range extension. Check List 3: 333-335 https://doi.org/10.15560/3.4.333

Teta P, Pardiñas UFJ, D'Elía G (2006) Rediscovery of Chacodelphys: a South American marsupial genus previously known from a single specimen. Mammalian Biology 71: 309-314. https://doi. org/10.1016/j.mambio.2006.03.004

Wang X, Auler AS, Edwards RL, Cheng H, Cristalli PS, Smart PL, Richards DA, Shen C-C (2004) Wet periods in northeastern Brazil over the past $210 \mathrm{kyr}$ linked to distant climate anomalies. Nature 432: 740-743. https://doi.org/10.1038/nature03067 